This page intentionally left blank 


\section{Sustainability by Design}

A Subversive Strategy for

Transforming Our

Consumer Culture

John R. Ehrenfeld

Yale University Press

New Haven and London 
“The Opening of Eyes," by David Whyte, from From Songs for Coming Home. Reprinted with permission from Many Rivers Press, Langley, Washington. www.davidwhyte.com.

"The Descent," by William Carlos Williams, from Collected Poems I939-I962, Volume II, copyright (CI948, I962 by William Carlos Williams. Reprinted by permission of New Direction Publishing Corp.

Copyright (C) 2008 by John R. Ehrenfeld

All rights reserved.

This book may not be reproduced, in whole or in part, including illustrations, in any form (beyond that copying permitted by Sections 107 and Io8 of the U.S. Copyright Law and except by reviewers for the public press), without written permission from the publishers.

Set in Sabon by Binghamton Valley Composition.

Printed in the United States of America.

The Library of Congress has cataloged the hardcover edition as follows: Ehrenfeld, John.

Sustainability by design : a subversive strategy for transforming our consumer culture / John R. Ehrenfeld.

p. $\mathrm{cm}$.

Includes bibliographical references and index.

ISBN 978-0-300-I3749-I (hardcover : alk. paper)

I. Sustainable development. 2. Consumption (Economics) I. Title. $\mathrm{HC}_{79 .} \mathrm{E}_{5} \mathrm{E}_{346} 2008$

$338.9^{\prime} 27-\mathrm{dc} 22$

2008012032

ISBN 978-0-300-I 5843-4 (pbk.)

A catalogue record for this book is available from the British Library.

I098765432I 
To my grandchildren 
This page intentionally left blank 
The Opening of Eyes

That day I saw beneath dark clouds

the passing light over the water

and I heard the voice of the world speak out,

I knew then, as I had before

life is no passing memory of what has been

nor the remaining pages of a great book

waiting to be read.

It is the opening of the eyes long closed.

It is the vision of far off things

seen for the silence they hold.

It is the heart after years

of secret conversing

speaking out loud in the clear air.

It is Moses in the desert

fallen to his knees before the lit bush.

It is the man throwing away his shoes

as if to enter heaven

and finding himself astonished,

opened at last,

fallen in love with solid ground.

_David Whyte, From Songs for Coming Home, @1 989 Many Rivers Press 
This page intentionally left blank 